\title{
Development of E-Content Using Segmentation Principles with E-Assessment in the Development of Teaching Materials Course
}

\author{
Desak Putu Parmiti ${ }^{1 *}$, Alexander Simamora ${ }^{1}$ \\ ${ }^{1}$ Program Studi Teknologi Pendidikan, Universitas Pendidikan Ganesha, Singaraja, Bali, Indonesia \\ *Corresponding author.Email: dsk-parmiti@undiksha.ac.id
}

\begin{abstract}
This study aims to produce e-content (electronic content) which is developed based on one of the multimedia principles, namely the segmentation principle. E-content is be presented segment by segment. After several segments, an eassessment will be presented which is used to measure the students' level of understanding after studying the material in the segment. The course material presented in e-content is a course on the development of teaching materials in the Undiksha FIP Educational Technology Study Program. Specifically, the objectives of this study are: (1) to produce econtent based on the principle of segmentation which is considered valid from the aspects of content, aspects of media and learning design, (2) to produce interesting e-content based on student assessments. This is a development research, and the e-content is developed using the $4 \mathrm{D}$ model that consists of 4 stages, namely define, design, development, and disseminate. Furthermore, the e-content is evaluated using formative evaluation [1] which includes (1) expert validation, (2) individual trials, and (3) small group trials. The subjects involved in this study were 1 content expert, 1 media expert as well as instructional design, 3 students in individual trials, and 9-12 students in small group trials. The methods and instruments used to collect data in this study were questionnaires. The questionnaire was used to collect data from content experts, media and learning design experts, and students according to the evaluation stage. The data obtained through a questionnaire were then analyzed using descriptive statistics. The development results show that, e-content has been successfully developed using the 4D model. Based on expert judgment, e-content is declared valid from the aspects of content, media and learning design. Likewise, based on student assessment that e-content has met the attractiveness aspect.
\end{abstract}

Keywords: E-Content, Segmentation Principles, E-Assessment

\section{INTRODUCTION}

The development of information technology has progressed very rapidly which has penetrated all sectors including the education sector. The sophistication of information technology has had many positive impacts on the world of education. For example, in the previous era, material was only presented through printed books, but in this digital era, materials can now be accessed through electronic devices without being limited by space and time. The development of technology also changes the learning styles and characteristics of students. In the past, students were still very dependent on their teachers/educators, but in the digital era, students can learn first through social media, YouTube, and other learning applications. In the past, students only learned from one learning source, but now they can learn from various sources provided on the internet.

The students' characteristic is influenced by the period of their birth. As it is known, the average students who study at the Undiksha FIP Educational Technology study program in 2020 are born after 1995 which is called $\mathrm{Z}$ generation [2]. $\mathrm{Z}$ generation has characteristics such as they are able to think globally, communicate digitally, socialize, mobile rapidly, and are into visual things (generationz.com.au). The characteristics of these students must be able to be facilitated by the teacher because their characteristics are quite different from previous generations. For example, their reading habits are very different from previous generations. Surveys were also conducted to find out these facts, for example related to book reading habits. The survey was conducted 
on Educational Technology students in February 2020

and the results are shown in the following graph.

How often do you read printed textbooks?

71 Respondent
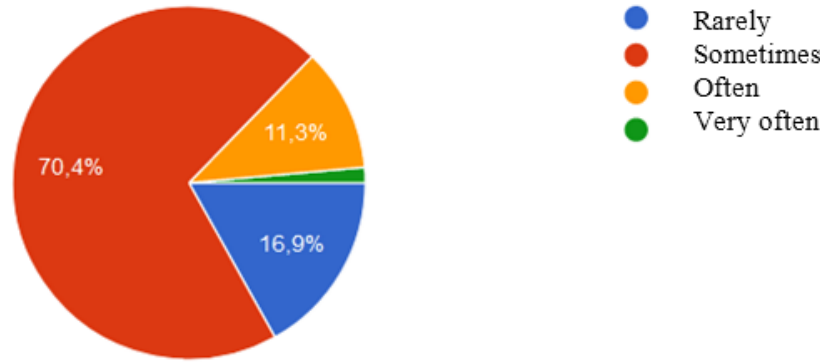

Figure 1 Survey Results on the Frequency of Students Reading Printed Books

The result of the survey shows that current students, especially those in the Education Technology Study Program, apparently "read text books occasionally" with a percentage of $70.4 \%$. This means that there is a shift in the reading culture from printed reading to digital reading material. This indicates that students today have quite different characteristics from students in previous eras. For this reason, teachers must be able to facilitate students by providing contents, learning strategies, media, and assessments in accordance with their characteristics.

In today's digital era, students who belong to $\mathrm{Z}$ generation have ample opportunities to access online lecture materials. Students can study the material they obtained before conducting face-to-face lectures. However, the material that students obtain has various characteristics and is not necessarily suitable

for every students' cognitive development. For example, the material is too dense, the order of the material is less systematic, lack of examples and so on. Although digital material is widespread on the internet, not much has been developed in accordance with learning theories and learning message design theories.

The assessment aspect also has an important role in addition to interesting digital materials. Without assessment, it is difficult to measure how far the content presented has been understood and mastered by students. In today's digital era, the assessment presentation pattern has undergone a change, from paper-based to onlinebased. In the past, giving feedback took a long time but nowadays feedback can be given directly and quickly.

Based on technological developments, the characteristics of $\mathrm{Z}$ generation students have developed an e-content accompanied by an e-assessment. The econtent being developed will adopt one of the multimedia principles, namely the segmentation principle. The segmentation principle provides a reference in designing messages that students will learn better when messages or content are presented in segments (parts) that can be arranged by students [3]. Based on the principle of segmentation, the material will be presented in sections and presented sequentially. Students have control to access material according to their learning speed. Students can choose text or image content for each segment. Students have time and access to organize the relationships between the text and images they learn. If students have completed it, they can continue studying to the next segment [3]. The application of the segmentation principle has had many positive results. The results showed that students learn better when the material is broken down into several parts and makes it easier for students who have lower memory capacities [4]. The application of the segmentation principle also has a positive effect on memory and application of material [5]. The application of the segmentation principle is also used to reduce the occurrence of excessive cognitive load on learners as expressed by [6] that when learners receive a continuous presentation containing interrelated concepts, the result is the cognitive system becomes overloaded and too much processing required. Learners do not have sufficient cognitive capacity to be involved in the required essential processing to understand the material. The solution to overcome this problem is to break the complex material into small segments.

The effectiveness of the presentation of the material using the segmentation principle is also accompanied by the presentation of e-assessment using information and communication technology (ICT). Assessment with the use of ICT as a means of communication as well as mastery of ICT is part of 21st century skills [7]. Thus, the use of ICT-based assessments is very relevant to develop these skills. ICT-based assessment or e-assessment is an assessment made by involving computer technology and internet networks in its use. 
The assessment that accompanies the e-content is presented according to the material segments so that it can be seen the level of understanding of the student after studying each segment of the material. It is assumed that the application of e-assessment will have a positive impact on students. As the research results show that eassessment can provide direct feedback, improve student performance, reduce educators' time and efforts, and reduce costs [8]. Thus, in this research, e-content is developed along with a valid e-assessment based on the assessment of experts and user trials (students).

\section{METHOD}

This research is a development research. [9] state that development research is research-oriented to develop and validate products used in education. The development model used by the 4D model is shown in Figure2.

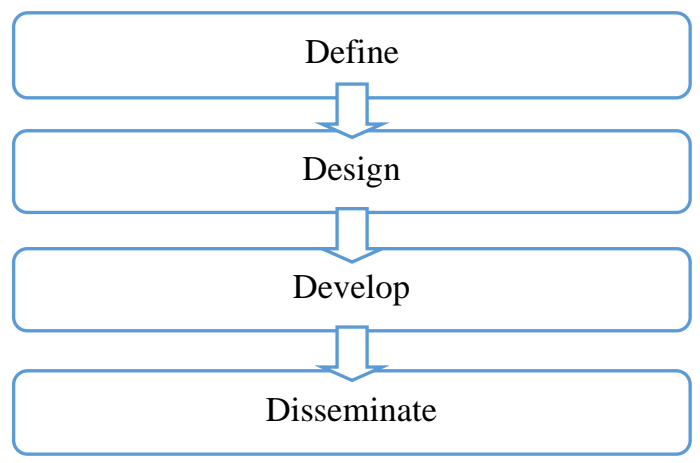

Figure 2 Stages of the 4D Model

The first stage of 4D model is define stage. There are three main activities in this stage namely: 1) Preliminary Final analysis which is an analysis of the problems underlying the development of e-content. The steps taken in this stage are to analyze problems, especially those related to basic competencies, learning objectives, and analysis of assessment tools; (2) Student analysis which is a stage to determine students' characteristics as well as their needs. This analysis deals with initial knowledge, learning styles, and learning support facilities; and (3) Task analysis which is aimed at identifying the types of assignments that can be applied to students after accessing e-content.

The second is the design stage where the e-content and the type of e-content that will be developed in the form of text, images, videos, and animation are designed. There are two focus activities in the design stage. The first focus is on developing e-content scripts. The second focus is the design of types of e-assessment in the form of rubrics and online drafts.

The Development Stage is to make the design into a real product. At the development stage, e-content production is carried out based on the draft. The production includes collecting materials (images, audio and video), combining materials, and editing. At this stage, a small review is also carried out by the production team to ensure that the e-content produced is in accordance with the draft.

The Dissemination Stage is where the expert validates the finished e-content. Validation activities are carried out by providing validation instruments to experts. The experts who act as validators are 1 media expert and 1 learning design expert. The suggestions from the validator are used as a basis for improvement or revision. After being revised, then it was tested on students to find out the level of attractiveness of e-content. The trial by students was carried out in two stages, namely the individual test stage involving 3 students and the small group test involving 12 students.

E-content as a result of development must go through a series of trials to determine its validity level. The level of validity of e-content can be determined through the analysis of expert reviews, individual tests and small group tests. The following is a product trial design. 


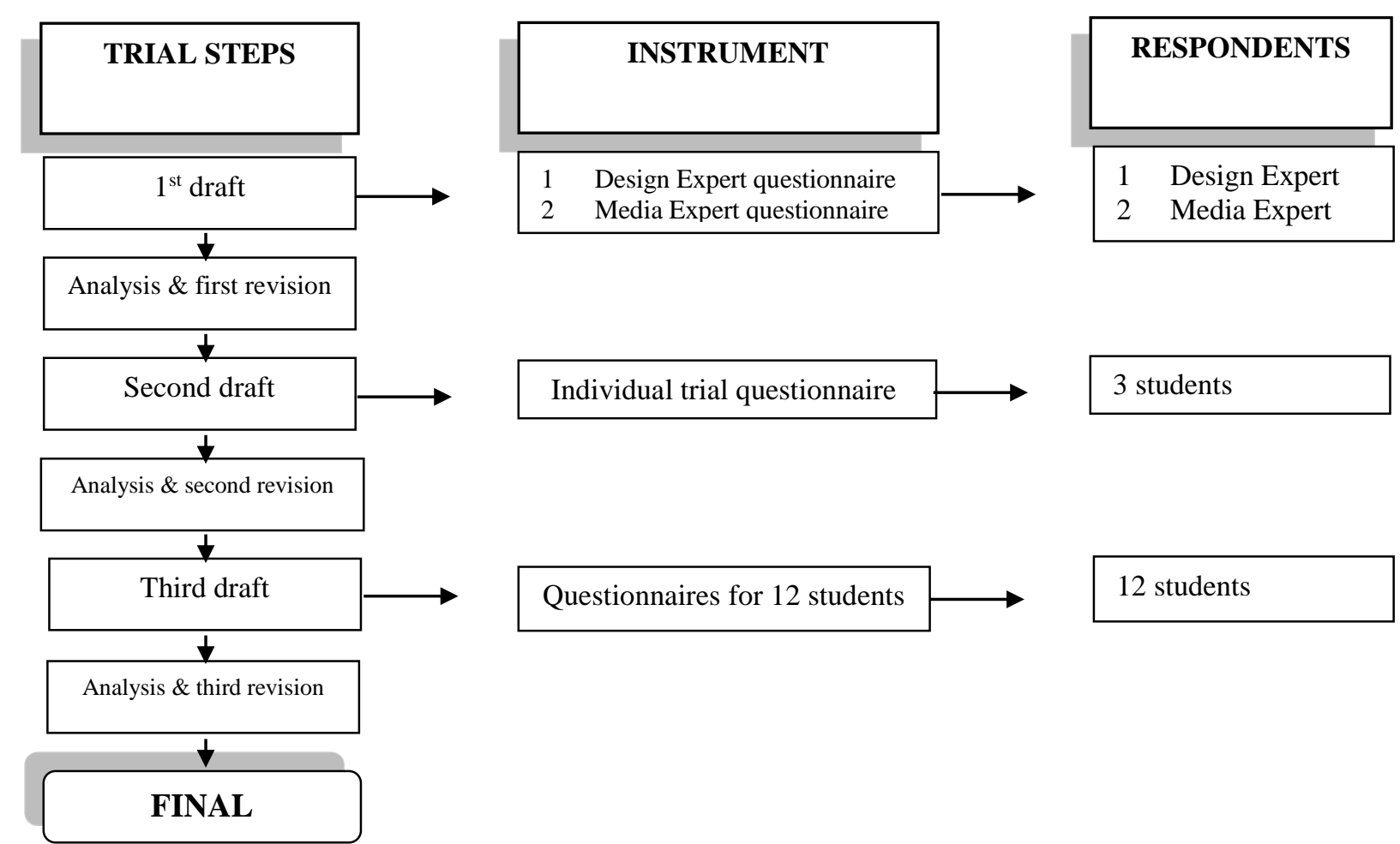

Figure 3 Product Development Draft Trial Design

The data were collected using questionnaire method. The questionnaire method was used in conducting preliminary studies and was used to obtain data from experts, individual trials and small group trials. To ensure the validity of the questionnaire, grid tables and writing instruments were used. The grid for the product validity test instrument is presented in Table 1.

Table 1. Grating of Product Validity Test Instruments

\begin{tabular}{|c|c|c|c|}
\hline No. & Formative Evaluation Stages & Aspects & Total \\
\hline 1 & Media Expert Validation & $\begin{array}{l}\text { 1. Typography } \\
\text { 2. Graphic } \\
\text { 3. Audio } \\
\text { 4. Layout } \\
\text { 5. Systematics }\end{array}$ & 10 \\
\hline 2 & Learning Design Validation & $\begin{array}{ll}\text { 1. } & \text { Competence } \\
\text { 2. Delivery strategy } \\
\text { 3. Evaluation }\end{array}$ & 8 \\
\hline 3 & Individual trial & $\begin{array}{ll}\text { 1. } & \text { Clarity } \\
\text { 2. } & \text { Attractiveness } \\
\text { 3. } & \text { Legibility } \\
\text { 4. Language } \\
\text { 5. } \\
\text { 6. } \text { Ability to motivate }\end{array}$ & 9 \\
\hline 4 & Small group trial & $\begin{array}{ll}\text { 1. } & \text { Clarity } \\
\text { 2. } & \text { Attractiveness } \\
\text { 3. } & \text { Legibility } \\
\text { 4. Language } \\
\text { 5. Ability to motivate } \\
\text { 6. }\end{array}$ & 9 \\
\hline
\end{tabular}

The data that has been collected using a questionnaire method, it then analyzed using descriptive statistical analysis. The analysis was done manually using the excel program. The guidelines used to provide meaning and decision making are presented in Table 2. 
Table 2. Guidelines for Conversion of Achievement Levels with a Scale of 5

\begin{tabular}{|c|c|l|}
\hline Achievement rate (\%) & Qualification & \multicolumn{1}{|c|}{ Information } \\
\hline $90-100$ & Very good & No need revision \\
\hline $75-89$ & Good & A little revision is needed \\
\hline $65-74$ & Enough & Revise sufficiently \\
\hline $55-64$ & Poor & A lot aspects should be revised \\
\hline $0-54$ & Very Poor & Recreate the product \\
\hline
\end{tabular}

\section{RESULT}

The result of this research is the electronic content used in the course of the development of teaching materials in the Educational Technology Study Program, Faculty of Education, Undiksha. The following describes the stages and results of each e-content development based on the segmentation principle.

\subsection{Define Stage}

Needs analysis is described in this stage which aims to find the problems experienced by students in participating in specific lessons in the Development of Teaching Materials in Educational Technology Study
Program of FIP Undiksha. Based on the observations it was found that: a) students rarely read books in print, b) student learning outcomes were not optimal, c) the material presented in a comprehensive and simultaneous manner tended to be difficult to be understood. The findings of these problems are used as a reference in developing an e-content to overcome weaknesses that occur in learning. After finding a problem in learning, then an analysis of student characteristics is carried out. The results of the student characteristic analysis are carried out as a reference in providing solutions to problems that have been found in the needs analysis phase. Furthermore, the results of the students' characteristics analysis are also used as a reference in developing e-content. The results of the analysis are presented in Table 3 .

Table 3 Results of Students' Characteristics Analysis

\begin{tabular}{|c|c|c|}
\hline No & Types of Characteristics & Result \\
\hline 1. & General Characteristics & $\begin{array}{l}\text { 1. Most of the students come from middle-low economy. Learning } \\
\text { sources are usually obtained by copying because it is cheaper } \\
\text { 2. All students have laptops and smartphone } \\
\text { 3. The average age of students is } 19-20 \text { years }\end{array}$ \\
\hline 2. & Competence & $\begin{array}{l}\text { 1. Students are familiar in operating computer } \\
\text { 2. Students are used to access information on the internet } \\
\text { 3. Students are familiar with Learning Management System (LMS) }\end{array}$ \\
\hline 3. & Motivation & $\begin{array}{l}\text { 1. Students' intrinsic motivation to develop themselves is good enough } \\
\text { 2. Students' intrinsic motivation tends to increase when the lectures are } \\
\text { more into practical or real activities rather than theoretical } \\
\text { presentation } \\
\text { 3. Organizing students in several efficient study groups that foster } \\
\text { external motivation }\end{array}$ \\
\hline 4. & Learning Style & $\begin{array}{l}\text { 1. Material presentation style } \\
\text { Generally, the students' learning style is concrete sequential which } \\
\text { means that the students prefer direct learning experience (hands on } \\
\text { experience) that are organized systematically. The example is by } \\
\text { using programmed exercises and learning activities. } \\
\text { 2. Information comprehension style } \\
\text { Generally, students prefer visual learning. The students will } \\
\text { understand better and easier if the materials are conveyed through } \\
\text { pictures, practicum, and demonstrations. }\end{array}$ \\
\hline
\end{tabular}

The results of the competency analysis and students' characteristics analysis are used as a reference for designing e-content. Thus, it is expected that e-content can approach students' characteristics in facilitating the learning process.

\subsection{Design Stage}

The e-content is designed in this stage. There are two focus activities in the design stage. First, the focus is on the content which includes: 1) determining objectives and focus (competency standards, basic competencies, success criteria), 2) planning the content of each econtent, and 3) designing the principle of segmentation 
into each content. The second focus is implementing the e-content design into a learning video script. The following is one of the designs for the application of the segmentation principle in e-content at the conceptual topic of the development of teaching materials.

Table 4. Segmentation Design

\begin{tabular}{|c|c|c|c|}
\hline No & Topic & Sub Topic & Segmentation \\
\hline \multirow[t]{3}{*}{1} & \multirow{3}{*}{$\begin{array}{l}\text { Conceptual } \\
\text { Teaching } \\
\text { Material } \\
\text { Development }\end{array}$} & $\begin{array}{l}\text { 1. Definition, form, purpose, } \\
\text { and fucntion of teaching } \\
\text { materials }\end{array}$ & $\begin{array}{l}\text { 1. What is teaching material } \\
\text { 2. Forms of teaching material } \\
\text { 3. Purpose and function of making teaching material }\end{array}$ \\
\hline & & $\begin{array}{l}\text { 2. Elements of teaching } \\
\text { materials and its differences } \\
\text { with learninng sources }\end{array}$ & $\begin{array}{l}\text { 1. Elements of teaching material } \\
\text { 2. The differences between teaching materials and } \\
\text { learning sources }\end{array}$ \\
\hline & & $\begin{array}{l}\text { 3. } \begin{array}{l}\text { Content of teaching } \\
\text { materials }\end{array} \\
\text { mats }\end{array}$ & $\begin{array}{l}\text { 1. Definition od the content of teaching material } \\
\text { 2. Component of teaching material }\end{array}$ \\
\hline
\end{tabular}

Based on the table 4, the 3 sub-subjects are divided into several segments. For example, in sub-subject 1 regarding the definition, form, purpose and function of teaching materials, they are divided into 3 segments, namely: (1) What are Teaching Materials, (2) Forms of Teaching Materials, and (3) Purpose and Functions of Making Teaching Materials.

\subsection{Develop Stage}

At the development stage, the design or design implementation is carried out. Here is a look at e-content.

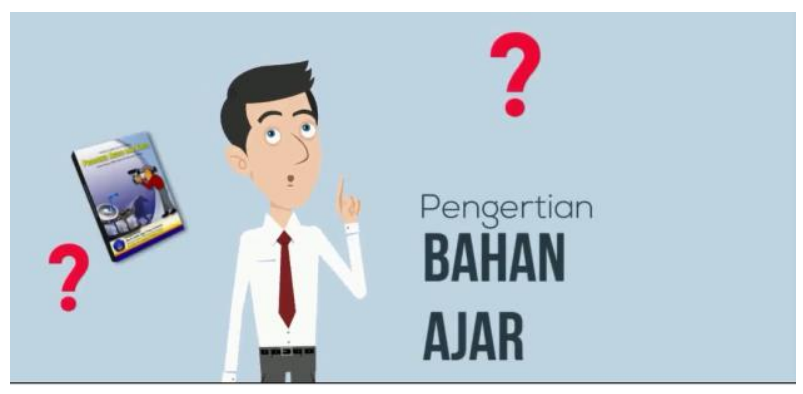

Figure 4 Definition of Teaching Materials segment

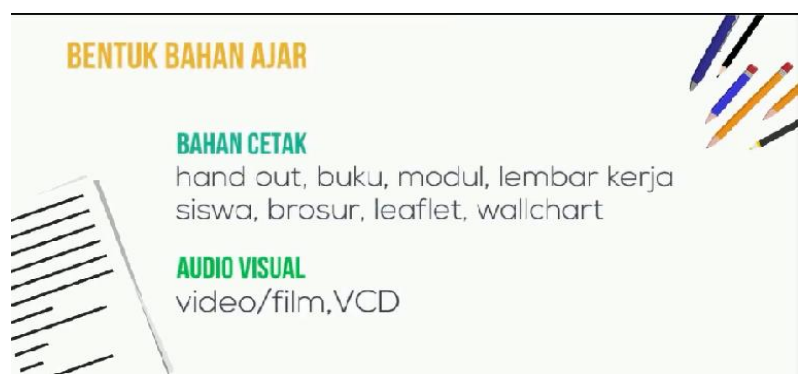

Figure 5 Kinds of Teaching Materials segment
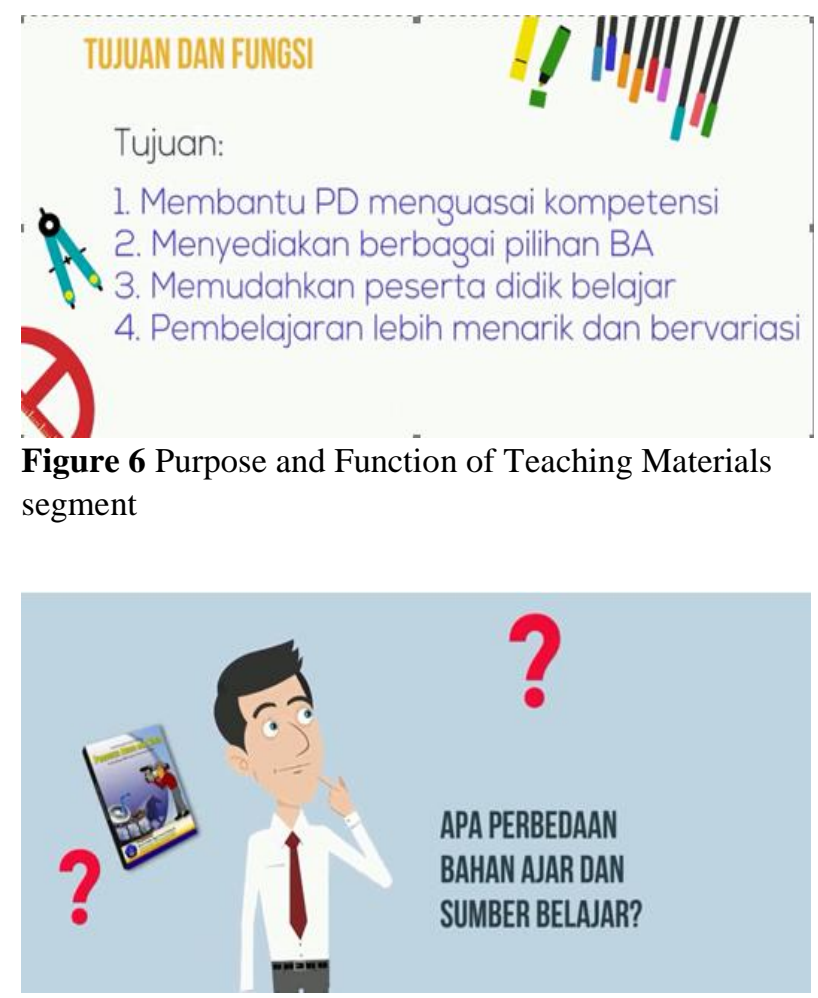

Figure 7 The difference of Teaching Materials and Learning Sources

Based on figure 4-7, it can be explained that everyone who accesses the e-content can listen to the material presented using the segmentation principle. The duration of each segment is between 1-2 minutes; thus, the student will not be overwhelmed. This kind of presentation is expected that students will understand the message and remember important points easily.

\subsection{Disseminate Stage}

In dissemination stage, e-content testing is carried out by experts and students. The test results by experts and students are presented in the table below. 
Table 5. Results of Experts test and Students test

\begin{tabular}{|l|l|c|c|}
\hline No & \multicolumn{1}{|c|}{ Testing Phase } & Percentage (\%) & Qualification \\
\hline 1. & Learning Media Expert review & 90 & Very Good \\
\hline 2. & Learning Design Expert review & 91 & Very Good \\
\hline 3. & Individual trial & 92 & Very Good \\
\hline 4. & Small group trial & 93 & Very Good \\
\hline
\end{tabular}

\section{RESULT AND DISCUSSION}

Based on the assessment of design and media experts, it can be concluded that the e-content developed is in good qualification. If it is examined from the aspect of learning design, the e-content developed has adopted the principle of segmentation. The principle of segmentation provides a reference for presenting large content which is then broken down into small segments. In this way, complex content will be divided into small parts and presented one by one [6]. The application of the segmentation principle will also reduce the cognitive load of learners and increase the occurrence of learning [10].

The results showed that the application of the segmentation principle accompanied by signalling and weeding was able to make it easier for learners to acquire knowledge and transfer knowledge [11]. Other research results also show that students' learning achievement is significantly better than the content presented without using segmentation [12].

Assessed from the aspect of learning media that econtent has been designed using message design theory. The theory adopted is that messages should be motivational and easy to be understood. The way that econtent can provide motivation is by presenting the opening page of e-content as attractive as possible, such as the use of question marks on topics such as "what is teaching material?". In presenting text content, it is also equipped with interesting and relevant images. If the image is the main focus, the image is placed on the left and the text is on the right. If the image is only as a support, the image is placed on the right and the text is on the left.

To make it easier to understand e-content messages, the principle of perception is also established in the form of presenting important material points. If the material is described in long texts, the message will be more difficult and can lead to misperception. If the message is presented in bullet points it will be easier to be understood. The material presented in the form of core material or material points can actually improve students' learning outcomes [13]. By paying attention to this theory, visual e-content becomes more organized and makes it easier for learners to understand and remember the content. The results showed that the role of visuals was able to improve conceptual understanding by learners [14]. Visualization that is presented in an integrated and relevant manner will provide a complete understanding to the students.
E-content development is also integrated with eassessment. The use of interactive assessments can spark the spirit of learners. E-content is integrated using eassessment through the Kahoot application. This quiz adopts a game model so that it further triggers the speed and accuracy of students in answering. This e-assessment is done online and students immediately receive feedback on the answers sent. Feedback is an important component that supports the effectiveness of learning [15]. The speed and accuracy of the answers really determine the students' rankings at each quiz session. The stimulus will make every student study more seriously so they can get the best ranking in quiz.

Based on individual and small group tests, the attractiveness of e-content is in very good qualification. The attractiveness of e-content is supported by the use of appropriate fonts, images, colors, sounds, and layouts. In e-content, a san serif typeface is used which has the same side size so that it can be seen clearly. Images used in econtent are relevant and interesting. Relevant means that it is in accordance with the text described so that students can easily perceive the text in question. Attractive means that the images used are attractive, have realistic colors, and do not have multiple meanings. The results showed that the use of images, colors, and sounds was able to attract attention and please the students [16]. The form of e-content is mostly in the form of videos with tutors. In addition, the method of presenting messages in e-content is more communicative so that the tutors' role in econtent seems to be communicating with the students. Using interactive videos will lead learning to be effective [17].

\section{CONCLUSION}

E-content has been developed using the principle of segmentation. The validity of the learning media aspect is $90 \%$ which is in the very good category and the validity of the learning design aspect is $91 \%$ which is also in the very good category. The attractiveness of e-content was carried out through user trials, namely in the individual test with the percentage of $92 \%$ which means that the attractiveness of digital content was in the very good category. In the small group trial, the percentage of $93 \%$ was obtained which was in the very good category. In order to produce a valid e-content, it is recommended to adopt one or more principles in multimedia. One of the important principles in today's digital era is the principle of segmentation. 


\section{REFERENCES}

[1] W. Dick, L. Carey, and J. O. Carey, The systematic design of instruction. Boston: Pearson, 2005.

[2] E. J. Cilliers, The Challenge Of Teaching Generation Z, PEOPLE Int. J. Soc. Sci., vol. 3, no. 1, 2017, pp. 188-198. DOI: 10.1080/00131727109340505.

[3] R. E. Mayer and R. Moreno, Nine ways to reduce cognitive load in multimedia learning, Educ. Psychol., vol. 38, no. 1, 2003, pp. 43-52, DOI: 10.1207/S15326985EP3801_6.

[4] P. Mayer, R. E., \& Chandler, When learning is just a click away: Does simple user interaction foster deeper understanding of multimedia messages?, J. Educ. Psychol., vol. 93, 2001, pp. 390-39.

[5] J. R. Doolittle, Peter E., Bryant, Lauren H. Chittum, Effects of degree of segmentation and learner disposition on multimedia learning, Br. J. Educ. Technol., vol. 46, no. 6, 2015.

[6] R. Clark, and Mayer, E-learning and the science of instruction. (3 ed.). San Fransico, 2011.

[7] S. C. Milligan, P. Griffin, E. Care, H. Slater, S. Harding, and Scoular, The Assessment And Teaching Of 21st Century Skills Mooc, 2014.

[8] N. Alruwais, G. Wills, and M. Wald, Advantages and Challenges of Using e-Assessment, Int. J. Inf. Educ. Technol., vol. 8, no. 1, 2018, pp. 34-37. DOI: 10.18178/ijiet.2018.8.1.1008.

[9] M. D. Borg, W. R. and Gall, Educational research: an introduction (7th ed.), New York: Longman, Inc, 2003.

[10] G. D. Rey, M. Beege, S. Nebel, M. Wirzberger, T. H. Schmitt, and S. Schneider, A Meta-analysis of the Segmenting Effect, vol. 31, no. 2, Educational Psychology Review, 2019.

[11]C. M. G. \& D. W. Mohamed Ibrahim, Pavlo D. Antonenko, "Effects of segmenting, signalling, and weeding on learning from educational video," Learn. Media Technol., vol. 37, no. 3, 2012, pp. 220-235, DOI: $10.1080 / 17439884.2011 .585993$.

[12]M. et al. Mayer, R.E., Howarth, J.T., Kaplan, Applying the segmenting principle to online geography slideshow lessons, Educ. Tech Res. Dev, vol. 66, 2018, pp. 563-577. DOI: https://doi.org/10.1007/s11423-017-9554-x.

[13] W. D. Riyanto and G. Gunarhadi, The Effectiveness of Interactive Multimedia in Mathematic Learning: Utilizing Power Points for Students with Learning Disability, IJPTE Int. J. Pedagog. Teach. Educ., vol.
1, no. 1, 2017, pp. 55-63. DOI: 10.20961/ijpte.v1i1.8400.

[14]F. Armansyah, S. Sulton, and S. Sulthoni, Multimedia Interaktif Sebagai Media Visualisasi Dasar-Dasar Animasi, J. Kaji. Teknol. Pendidik., vol. 2, no. 3, 2019, pp. 224-229. DOI: 10.17977/um038v2i32019p224.

[15] A. Khamparia and B. Pandey, Impact of interactive multimedia in E-learning technologies: Role of multimedia in E-learning, Enhancing Acad. Res. With Knowl. Manag. Princ., no. April, 2017, pp. 199-227. DOI: 10.4018/978-1-5225-2489-2.ch007.

[16]J. Kuswanto et al., Pengembangan Multimedia Pembelajaran pada Mata Pelajaran Teknologi Informasi dan Komunikasi Kelas VIII, Innov. J. Curric. Educ. Technol. IJCET, vol. 6, no. 2, 2017, pp. 58-64. [Online]. Available: https://journal.unnes.ac.id/sju/index.php/ujet.

[17]D. Zhang, L. Zhou, R. O. Briggs, and J. F. Nunamaker, Instructional video in e-learning: Assessing the impact of interactive video on learning effectiveness, Inf. Manag., vol. 43, no. 1, 2006, pp. 15-27. DOI: 10.1016/j.im.2005.01.004. 